\title{
The Impact of Industrial Pollution with Toxic Gases on Stem Histological Parameters of Woody Plant Undergrowth under Conditions of the Southern Industrial Zone of the City of Dnipro, Ukraine
}

\author{
Tetiana lusypiva $^{1 \mathrm{a}}$ and Galyna Miasoid ${ }^{2, b,{ }^{*}}$ \\ ${ }^{1}$ Associate Professor, The Department of Plant Physiology and Introduction, \\ Oles' Honchar Dnipropetrovsk National University, Gagarina str., 72, Dnipro, Ukraine - 49010 \\ ${ }^{2}$ Associate Professor, The Department of International Tourism and Language Training, \\ Alfred Nobel University, Sicheslavska Naberezhna str., 18, Dnipro, Ukraine - 49055 \\ a JusypivaTatjana@i.ua, b galyna.miasoid@gmail.com
}

Keywords: woody plant undergrowth, stem histological indices, toxic gases, planting

\begin{abstract}
The paper examines the influence of industrial emissions of sulphur (IV) and nitrogen (IV) oxides (the southern industrial zone of the city of Dnipro) on stem histological parameters of the autochthonous woody plant species undergrowth of Acer platanoides L. and Fraxinus excelsior L., which are natural forest edificators in the steppe zone of Ukraine. It shows that stem anatomical characteristics undergo quantitative changes in the annual undergrowth shoots of the two tree species under anthropogenic burden, with the most significant changes in the area of heavy pollution. Results indicate the decrease of such stem parameters as stem and stele diameters, wood radius and primary cortex thickness under high concentrations of $\mathrm{SO}_{2}$ and $\mathrm{NO}_{2}$ in seedlings of both species. However, this parameter drops in A. platanoides stems by reducing the collenchyme width, whereas it goes down in F. excelsior stems due to cork thickness loss. Another difference in the response of $A$. platanoides to the influence of phytotoxic pollutants compared to $F$. excelsior is the depletion of conducting elements of its phloem, which results in thinning the secondary cortex of the stem. The research findings prove high vulnerability of A.platanoides undergrowth to the chronic exposure of $\mathrm{SO}_{2}$ and $\mathrm{NO}_{2}$. Therefore, this woody species is suggested to be used as a test object in monitoring research on plants of virginal group in the technogenic areas contaminated with sulphur (IV) and nitrogen (IV) oxides.
\end{abstract}

\section{Introduction}

The nature of the Prydniprovya region is exposed to strong anthropogenic pressure, because there are large enterprises and concerns of metallurgical, chemical, energy, engineering and other industries and agriculture and a very extensive system of roads with heavy traffic of trucks and cars concentrated there [1]. The enterprises produce a huge number of pollutants, including toxic $\mathrm{SO}_{2}$ and $\mathrm{NO}_{2}$ gases. The most vulnerable objects of their chronic attack are artificial forest ecosystems in the steppe zone of Ukraine as their location is inconsistent with geographical conditions of their natural habitat because of mismatch of forest and steppe circulation of substances, as well as ecological conditions, such as hard groundwater and climatic conditions [2]. The degree of degradation of the woody plant communities cannot be estimated without examining the process of their self-renewal, the most important stage of which is growth and development of the undergrowth of the nurse and associate woody species.

A range of methods is used to study the state of the virginal tree clusters in terms of manmade conditions of growth such as physiological and biochemical, biometric and physical-chemical methods of plant research, but environmental-and-anatomical method is the most relevant research method nowadays. It makes it possible to detect quantitative and qualitative changes in tissues and plant organs under the influence of extreme environmental factors and identify the mechanisms of plant resistance to anthropogenic pollution of the biosphere [3-5].

Having analyzed the previous research on the influence of anthropogenic pollution on the stem anatomical structure of self-seeding and undergrowth of woody plants, we concluded that this 
issue has hardly been investigated. There is profound research of the changes in the histological structure of stems of annual and perennial shoots of coniferous species [5-7 et al.] and angiosperm woody plants [8-12 et al.], which have reached vegetative and generative stages of their development. There is also some research on the action of heavy metals, toxic gases and other pollutants on the anatomical structure of leaves, needles or roots [13-15], and stems [16] of woody plants at the early stages of ontogenesis. However, no research has been undertaken to study the problem of the impact of technogenic pollution of the environment with $\mathrm{SO} 2$ and $\mathrm{NO} 2$ on histological elements of annual shoots of woody seedlings in conditions of the steppe zone of Ukraine. Therefore, the present paper seeks to examine the changes in histological parameters of Acer platanoides L. and Fraxinus excelsior L. stem undergrowth exposed to chronic industrial emissions of $\mathrm{SO}_{2}$ and $\mathrm{NO}_{2}$ in conditions of the southern industrial zone of Dnipro (Ukraine).

\section{Materials and Methods}

\section{Study area}

The research was conducted in the city of Dnipro, which is the regional center of Dnipropetrovsk oblast, i.e. region. This region is the part of the Prydniprovya social and economic zone of Ukraine, which ranks second in the country in terms of its industrial development and which is provides the country with $53.0 \%$ of metallurgical products, $19.0 \%$ of the products of machine-building, chemical and petrochemical industries, and $23.5 \%$ of the country's electricity supply [17].

The zone is called Prydniprovya because of its geographical position. The region is situated in the northern-eastern part of in the middle and downstream Dnipro River, the main river of Ukraine [1]. The Prydniprovya region is also a part of the steppe physiographic zone with moderate continental climate characteristic of hot summer and dry winter [2]. Windy weather is common to the steppe Prydniprovya during 270-298 days a year. As for the wind diagram, west and northwest winds prevail in winter, while winds from the east and northeast predominate in summer.

The major grounds are ordinary black soil; the predominant vegetation type is steppe vegetation since the most of the steppes are tilled. As the plain relief is crossed with valley of the Dnipro River and its tributaries, cutbanks and small flat-bottom valleys, there are some other vegetation types, like forest vegetation (ravine forests), meadow vegetation, and bog vegetation [2]. Recent research states that the amount of woodland in Dnipropetrovsk region makes $2.41 \%$. However, the most part of them are of artificial origin and of sanitary and protective value, and including those around industrial enterprises [1].

Agroclimatic indices in the research area (the city of Dnipro) are as follows: hydrothermal factor 0.8-0.9; rainfall during the vegetation season 250-270 mm; annual rainfall of 410-490 (460) $\mathrm{mm}$; humidity at $13.00 \mathrm{pm}$ (July) is $43-46 \%$; average air temperature in January is $4^{\circ} \mathrm{C} \ldots-7^{\circ} \mathrm{C}$, July $+21{ }^{\circ} \mathrm{C} \ldots+23^{\circ} \mathrm{C}$; average annual temperature is $+8.4^{\circ} \mathrm{C}$; average minimum temperature of $-23^{\circ} \mathrm{C}$; absolute minimum temperature of $-38^{\circ} \mathrm{C}$; frost-free period of $150-185$ days; absolute maximum temperature of $40^{\circ} \mathrm{C}$; soil frost depth of $50-70 \mathrm{~cm}$; spring frosts recorded to 21 April in the air, and to May 10 on the ground; autumn frosts begin the second decade of October; during winter thaws temperatures can rise to $+14^{\circ} \mathrm{C}[2,18]$.

Dnipro is a powerful multi-industrial center of Ukraine [19], which has more than 200 companies united in 4 major industrial regions: Western, Left-bank, Southern and Eastern, or 27 small industrial sites. The most contaminated areas are the western and the southern areas, the latter includes the CJSC 'Plant Dnipropres' (hereinafter 'Dnipropres') [20].

Thus, the study area is characterized by a combination of climatic, soil and hydrological conditions and man-made factors, which are extreme for growth and development of woody plants. 


\section{Monitoring points}

Storage plant material was collected in 3 monitoring points (fig. 1): two test areas, which are located near the Dnipropres, and a reference area. Monitoring point 1 is characterized by the highest pollution rate and is located as far as $500 \mathrm{~m}$ to the southwest of the source of industrial emission $\left(48^{\circ} 39^{\prime} 03.4^{\prime \prime} \mathrm{N}, 34^{\circ} 99^{\prime} 50.6^{\prime \prime}\right.$ E.) It features average concentrations of toxic gases as indicated below: $\mathrm{SO}_{2}-0.31 \mathrm{mg} / \mathrm{m}^{3}, \mathrm{NO}_{2}-0.26 \mathrm{mg} / \mathrm{m}^{3}$. An average pollution rate is found at monitoring point 2 as far as $2000 \mathrm{~m}$ to the south of the plant $\left(48^{\circ} 38^{\prime} 00.8^{\prime \prime} \mathrm{N}, 35^{\circ} 00^{\prime} 17.5^{\prime \prime} \mathrm{E}\right)$, where the concentrations of $\mathrm{SO}_{2}$ and $\mathrm{NO}_{2}$ are $0.29 \mathrm{mg} / \mathrm{m}^{3}$ and $0.24 \mathrm{mg} / \mathrm{m}^{3}$ accordingly. The relatively clean reference area [20-22] is located in the Botanical garden of Oles' Honchar Dnipropetrovsk National University $\left(48^{\circ} 43^{\prime} 67.6^{\prime \prime} \mathrm{N}, 35^{\circ} 04^{\prime} 04.2^{\prime \prime} \mathrm{E}\right)$, where the concentrations of sulphur (IV) and nitrogen (IV) oxides do not exceed the maximum permitted values $\left(\mathrm{SO}_{2}-0.05 \mathrm{mg} / \mathrm{m}^{3}, \mathrm{NO}_{2}-0.04 \mathrm{mg} / \mathrm{m}^{3}\right)$ according to the City Sanitation Committee report.

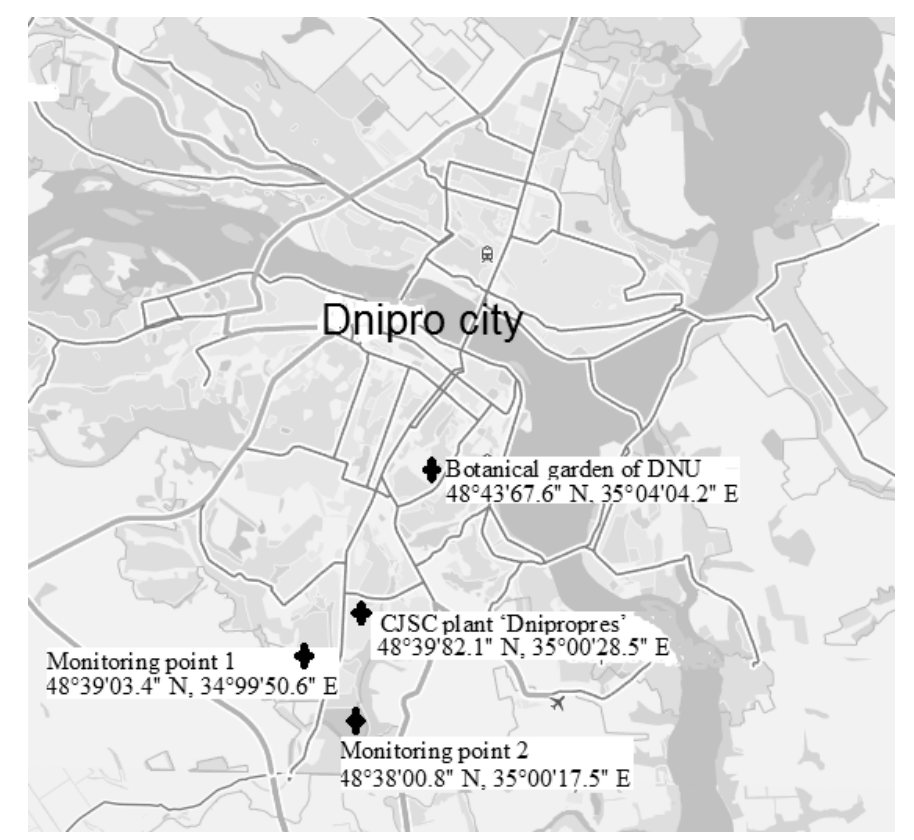

Fig. 1. The map of Dnipro city and the sites of monitoring points [23]

\section{Plant material}

The objects of study were undergrowth of the autochthonous species of Norway maple Acer platanoides L. (Aceraceae Juss.) and European ash Fraxinus excelsior L. (Oleaceae Hoffmgg. et Link.). In each of the multiple monitoring points 30-50 annual shoots of undergrowth from each of the woody species were selected. The samples were fixed in $96.0 \%$ ethanol. The stem cross sections of were made at a distance of $2 \mathrm{~cm}$ from the base of the shoot. To identify the lignified cells the cross sections were stained with $1.0 \%$ solution of phloroglucinol [4]. BRESSER Biolux LCD 40x-1600x a light microscope was used to measure the tissue thickness with an amplification of 100 times. The replication was $30-50$ stem cross sections for each monitoring point.

\section{Statistical Analysis}

The results of the study were handled using a multifunctional application software package STATGRAFICS. Mean absolute error was calculated. To compare the anatomical parameters in woody plant undergrowth stems of reference and test samples Student's t-test $(p<0.05)$. Normality allocation of the sample had been preliminary assessed. 


\section{Results}

The data presented in Tables 1-4 clearly demonstrate, that phytotoxic pollutants cause the changes in anatomic indices of undergrowth of the studied species. However, these changes vary among the species.

The impact of industrial pollution on the structure of primary cortex of woody plant undergrowth stems

The analysis of Table 1 proves that the primary cortex thickness decreases in F. excelsior undergrowth in both of the test areas with sacrifice in phellem. This index decreases in the plants of A. platanoides in the area characterized by the highest pollution rate, but it increases to some extent within the area of average contamination as the result of certain changes in collenchyme thickness.

Table 1. Impact of $\mathrm{SO}_{2}$ and $\mathrm{NO}_{2}$ on the size of histological elements of the primary cortex of annual shoot stems of woody plant undergrowth

\begin{tabular}{|c|c|c|c|}
\hline Indicator & $\begin{array}{l}\text { Control } \\
(\mathrm{n}=50)\end{array}$ & $\begin{array}{l}\text { Monitoring point } 1 \\
\quad(\mathrm{n}=50)\end{array}$ & $\begin{array}{c}\text { Monitoring point } 2 \\
(\mathrm{n}=30)\end{array}$ \\
\hline \multicolumn{4}{|c|}{ Acer platanoides } \\
\hline Cork Thickness $[\mu \mathrm{m}]$ & $47.05 \pm 3.29$ & $36.29 \pm 0.75^{*}$ & $48.39 \pm 0.01$ \\
\hline Collenchyme Thickness $[\mu \mathrm{m}]$ & $55.11 \pm 1.93$ & $43.01 \pm 3.83 *$ & $65.67 \pm 4.26^{*}$ \\
\hline Primary Cortex Parenchyma & & & \\
\hline Thickness $[\mu \mathrm{m}]$ & $28.23 \pm 3.25$ & $26.88 \pm 8.33$ & $33.87 \pm 8.83$ \\
\hline Primary Cortex Thickness $[\mu \mathrm{m}]$ & $130.38 \pm 4.80$ & $104.85 \pm 9.31 *$ & $147.86 \pm 6.32 *$ \\
\hline \multicolumn{4}{|c|}{ Fraxinus excelsior } \\
\hline Cork Thickness $[\mu \mathrm{m}]$ & $69.90 \pm 8.07$ & $49.40 \pm 2.85^{*}$ & $47.05 \pm 3.29 *$ \\
\hline Collenchyme Thickness $[\mu \mathrm{m}]$ & $95.63 \pm 3.04$ & $83.34 \pm 6.59$ & $100.81 \pm 8.07$ \\
\hline Primary Cortex Parenchyma & & & \\
\hline Thickness $[\mu \mathrm{m}]$ & $135.31 \pm 24.79$ & $102.83 \pm 12.10$ & $91.40 \pm 8.32$ \\
\hline Primary Cortex Thickness $[\mu \mathrm{m}]$ & $300.61 \pm 24.80$ & $236.31 \pm 21.31^{*}$ & $241.95 \pm 10.20^{*}$ \\
\hline
\end{tabular}

* - differ significantly from control $(\mathrm{p}<0.05)$

The impact of industrial pollution on the structure of the secondary cortex of woody plant undergrowth stems

As can be seen from Table 2, the thickness of the secondary cortex remains steady in comparison with the plants in the relatively clean area in the stems of A. platanoides undergrowth in the average pollution area, and in F. excelsior in the area of heavy pollution. This section of the stem decreases in the former species in Monitoring point 1, whereas it rises in Monitoring point 2 in the latter of the species due to corresponding changes in the hard bast thickness.

Table 2. Impact of $\mathrm{SO}_{2}$ and $\mathrm{NO}_{2}$ on the size of histological elements of the secondary cortex of annual shoot stem of woody plant undergrowth

\begin{tabular}{|l|c|c|c|}
\hline \multicolumn{1}{|c|}{ Indicator } & $\begin{array}{c}\text { Control } \\
(\mathrm{n}=50)\end{array}$ & $\begin{array}{c}\text { Monitoring point 1 } \\
(\mathrm{n}=50)\end{array}$ & $\begin{array}{c}\text { Monitoring point 2 } \\
(\mathrm{n}=30)\end{array}$ \\
\hline \multicolumn{4}{|c|}{ Acer platanoides } \\
\hline Hard Bast Thickness $[\mu \mathrm{m}]$ & $54.44 \pm 4.03$ & $56.46 \pm 3.47$ & $61.29 \pm 4.42$ \\
Soft Bast Thickness $[\mu \mathrm{m}]$ & $76.62 \pm 5.92$ & $60.49 \pm 4.66^{*}$ & $77.42 \pm 4.65$ \\
Secondary Cortex Thickness $[\mu \mathrm{m}]$ & $133.07 \pm 6.01$ & $116.98 \pm 5.31^{*}$ & $139.41 \pm 13.15$ \\
\hline \multicolumn{4}{|c|}{ Fraxinus excelsior } \\
\hline Hard Bast Thickness $[\mu \mathrm{m}]$ & $63.62 \pm 2.69$ & $65.86 \pm 3.29$ & $84.68 \pm 8.07^{*}$ \\
Soft Bast Thickness $[\mu \mathrm{m}]$ & $99.47 \pm 18.03$ & $98.78 \pm 3.73$ & $96.78 \pm 10.20$ \\
Secondary Cortex Thickness $[\mu \mathrm{m}]$ & $164.76 \pm 14.62$ & $166.34 \pm 7.39$ & $181.46 \pm 15.44^{*}$ \\
\hline
\end{tabular}

$*$ - differ significantly from control $(\mathrm{p}<0.05)$ 


\section{The impact of industrial pollution on the structure of the wood and pith of woody plant undergrowth}

The analysis of the data presented in Table 3 indicates that the radius of xylem in F. excelsior undergrowth stems in the both monitoring points reduces significantly compared to the reference value. However, it shows the similar decrease in the stems of $A$. platanoides plants only in the area of high pollution with toxic gases. The pith diameter index also drops significantly, but only under high concentrations of industrial emissions of $\mathrm{SO}_{2}$ and $\mathrm{NO}_{2}$. The thickness of the perimedullary zone (the peripheral pith zone) [3] or medullary sheath [24] does not differ from the control values in A. platanoides in the both monitoring points, while $F$. excelsior only differs in the area of high air pollution with toxic gases. In the area of average pollution rate the stem histological element index of $F$. excelsior undergrowth is significantly higher than the indicator in the control plants.

\section{The impact of industrial pollution on the stem diameter of woody plant undergrowth}

As can be seen from the data in Table 4, the central cylinder diameter in the stems of $A$. platanoides and $F$. excelsior decreases only in the high pollutant rate area, while it remains stable in the area of average pollution with toxic gases, so, the difference between in values of this parameter in the test area (Monitoring point 2) and the reference area is statistically insignificant $(\mathrm{p}<0.05)$. We have found a similar trend in the stem diameter, since this parameter only decreases in Monitoring point 1.

Table 3. Impact of $\mathrm{SO}_{2}$ and $\mathrm{NO}_{2}$ on the pith diameter, medullary sheath thickness and wood radius of the annual shoot of woody plant undergrowth stem

\begin{tabular}{|l|c|c|c|}
\hline \multicolumn{1}{|c|}{ Indicator } & $\begin{array}{c}\text { Control } \\
(\mathrm{n}=50)\end{array}$ & $\begin{array}{c}\text { Monitoring point 1 } \\
(\mathrm{n}=50)\end{array}$ & $\begin{array}{c}\text { Monitoring point 2 } \\
(\mathrm{n}=30)\end{array}$ \\
\hline \multicolumn{4}{|c|}{ Acer platanoides } \\
\hline Wood Radius $[\mu \mathrm{m}]$ & $498.69 \pm 38.25$ & $395.19 \pm 16.92^{*}$ & $424.76 \pm 24.64$ \\
Medullary sheath thickness $[\mu \mathrm{m}]$ & $49.73 \pm 3.29$ & $51.08 \pm 6.59$ & $53.23 \pm 4.42$ \\
Minor Pith Diameter $[\mu \mathrm{m}]$ & $1704.40 \pm 81.54$ & $1447.67 \pm 57.97 *$ & $1573.83 \pm 84.26$ \\
Major Pith Diameter $[\mu \mathrm{m}]$ & $2193.68 \pm 142.46$ & $1576.71 \pm 106.49^{*}$ & $1925.92 \pm 142.73$ \\
\hline \multicolumn{4}{|c|}{ Fraxinus excelsior } \\
\hline Wood Radius $[\mu \mathrm{m}]$ & $384.52 \pm 25.08$ & $307.81 \pm 27.19^{*}$ & $250.01 \pm 13.50^{*}$ \\
Medullary sheath thickness $[\mu \mathrm{m}]$ & $61.29 \pm 6.21$ & $67.21 \pm 11.02$ & $83.33 \pm 6.59^{*}$ \\
Pith Diameter $[\mu \mathrm{m}]$ & $2436.57 \pm 252.79$ & $1854.95 \pm 136.11 *$ & $2248.52 \pm 214.56$ \\
\hline
\end{tabular}

* - differ significantly from control $(\mathrm{p}<0.05)$

Table 4. Impact of $\mathrm{SO}_{2}$ and $\mathrm{NO}_{2}$ on the stem and central cylinder diameter of the annual shoot of woody plant undergrowth stem

\begin{tabular}{|l|c|c|c|}
\hline \multicolumn{1}{|c|}{ Indicator } & $\begin{array}{c}\text { Control } \\
(\mathrm{n}=50)\end{array}$ & $\begin{array}{c}\text { Monitoring } \\
\text { point 1 }(\mathrm{n}=50)\end{array}$ & $\begin{array}{c}\text { Monitoring } \\
\text { point 2 }(\mathrm{n}=30)\end{array}$ \\
\hline \multicolumn{3}{|c|}{ Acer platanoides } \\
\hline Minor Central Cylinder Diameter $[\mu \mathrm{m}]$ & $3089.88 \pm 115.12$ & $2575.39 \pm 201.32 *$ & $2808.65 \pm 163.16$ \\
Major Central Cylinder Diameter $[\mu \mathrm{m}]$ & $3573.48 \pm 194.03$ & $2704.91 \pm 163.97 *$ & $3158.87 \pm 196.17$ \\
Minor Stem Diameter $[\mu \mathrm{m}]$ & $3343.64 \pm 128.74$ & $2783.89 \pm 205.71 *$ & $3104.35 \pm 243.11$ \\
Major Stem Diameter $[\mu \mathrm{m}]$ & $3832.16 \pm 209.43$ & $2912.91 \pm 254.92 *$ & $3456.44 \pm 176.82$ \\
\hline \multicolumn{3}{|c|}{ Fraxinus excelsior } \\
\hline Central Cylinder Diameter $[\mu \mathrm{m}]$ & $3648.78 \pm 126.43$ & $2974.88 \pm 117.35 *$ & $3278.46 \pm 187.54$ \\
Stem Diameter $[\mu \mathrm{m}]$ & $4250.99 \pm 309.71$ & $3447.39 \pm 234.78 *$ & $3762.32 \pm 174.95$ \\
\hline
\end{tabular}

* - differ significantly from control $(\mathrm{p}<0.05)$ 


\section{Discussions}

Plant biology and environmental physiology describe quantitative anatomical changes [3, 4]. This research also reveals significant changes in the size of a range of histological parameters of annual shoot stems of A.platanoides and F. excelsior undergrowth influenced by industrial emissions of $\mathrm{SO}_{2}$ and $\mathrm{NO}_{2}$.

\section{The impact of industrial pollution on the structure of the primary cortex of woody plant undergrowth stems}

The structure of the primary cortex includes cork (basic part of tectorial tissue of the periderm), strengthening tissue of collenchyme and cortex parenchyma. The previous studies showed that the primary cortex of young shoots of plants is highly sensitive to anthropogenic environmental factors, and proved that plants of different tree species are characterized by different changes in the size of histological elements of the stem primary cortex in response to the phytotoxic pollutant impact. Thus, Golikova (2011) studied the effect of emissions of Prydniprovska TPP (the main toxic substances were $\mathrm{NOx}, \mathrm{SO}_{2}, \mathrm{CO}$, solid impurities) on the structure of the stem of the Acer L. genus. The author found an increase in thickness of periderm and collenchyme in A. platanoides, A. pseudoplatanus L. and A. saccharinum L., and explained this by the adaptive response of plants to the effect of anthropogenic load. There were no changes in dimensions in the tissues of $A$. negundo L. stems. Golikova also registered the increase in the thickness of cortex parenchyma in such species as A.pseudoplatanus and A. saccharinum and its reduction in A. negundo and A. platanoides. In our previous research we found that sulphur (IV) and nitrogen (IV) oxides affect the plants of Robinia pseudoacacia L. as their sprouting demonstrate thicker phellem, collenchyme and primary cortex, although these indices remain similar to the reference values in the undergrowth $[25,26]$.

The conducted analysis the structure of the primary cortex of the stem (Table 1) shows the reduction of its thickness in the undergrowth $F$. excelsior in both of the research areas $(21.4 \%$ and $19.5 \%$ in Monitoring points 1 and 2 respectively compared to the reference value). In plants of A. platanoides there was a decrease of the studied parameter by $19.6 \%$ only in an area of high rate of toxic emissions in the atmosphere, whereas this value increased by $13.4 \%$ in the area of average industrial emissions of Dnipropres.

The findings of this study clearly demonstrate that different wood species undergo different histological changes of the primary cortex elements. For example, phellem thickness significantly decreases in F. excelsior plants in Monitoring points 1 and 2 by $29.3 \%$ and $32.7 \%$ respectively compared to the reference area. These changes in the width of the strengthening tissue of the primary cortex and cortex parenchyma are insignificant with $\mathrm{p}<0.05$. In the undergrowth A. platanoides the reduction of the primary cortex thickness in Monitoring point 1 relates to the decrease of width of both the phellem and collenchyme by $22.9 \%$ and $22.0 \%$ correspondently compared to the reference values. At Monitoring point 2 the phellem thickness holds steady compared to the control value, and that of the strengthening tissue even rises by $19.2 \%$, which results in the thickening of the primary cortex of test plants compared to the plants in the relatively clean zone. It should be noted that the seedling stems of the studied species have various types of collenchyme: A.platanoides has radial collenchyme of 7-8 rows of cells while F.excelsior collenchyme is plate-angled and is formed with 5-6 cell rows.

It is known that the cortical layer does not leak liquid and gases [27], has poor thermal conductivity and protects plants from drought, overheating and other adverse environmental factors $[3,24]$. Therefore, in case of significant thinning of phellem that occurs under chronic effects of sulphur (IV) and nitrogen (IV) oxides on the undergrowth of $F$. excelsior and A. platanoides, plant resistance to these types of toxic gas emissions can be reduced. 


\section{The impact of industrial pollution on the structure of the secondary cortex of woody plant undergrowth stems}

The scholars distinguish the following histological elements in the secondary cortex: soft bast, formed by conducting elements of the phloem (sieve tube and companion cells) and bast parenchyma and hard bast as its strengthening tissue (bast fibers), which cells have lignified cell walls in the studied species [27]. Phloem development is of great importance for correlative relationships of organs in a plant because it provides transport of photosynthesis products to the roots, stems and buds that grow and develop. However, according to scholars from the field of environmental anatomy and physiology of plants, industrial emissions and motor vehicle emissions cause changes in the structure or size of bast in many woody and brushwood species. So, Dmuchowski, Kurczynska \& Wloch (1998) note that high rate of steelmaking industry emissions inhibiting the mitotic activity of the cambial zone in the Pinus sylvestris L. stems lead to reduction of the number of phloem cells at different stem height levels. Griztay \& Shupranova (2015) found that the secondary cortex if the stems of Tilia cordata Mill. depletes when exposed to power plant emission ( $\mathrm{SO}_{2}, \mathrm{NO}_{\mathrm{x}}$, solid impurities), which is associated with shrinkage of mostly soft bast, and to some extent due to the thinning of the hard bast. The authors assume that this may cause a decrease in physiological activity of the tree species due to slowing the transportation of organic compounds from assimilatory to other plant organs. The thickness of the stem phloem in other tested species of the genus Tilia L. (T. europaea L. and T. platyphyllos Scop.) in both test and reference plants were on a level. Iusypiva \& Miasoid (2016) found an increase in the thickness of the secondary cortex of the stems of Salix alba L. in conditions of chronic exposure of $\mathrm{SO}_{2}$ and $\mathrm{NO}_{2}$ by increasing the width of the hard bast.

The present research findings show that the secondary cortex thickness in A.platanoides undergrowth remains unchanged in the area of average contamination, whereas in an area with high levels of $\mathrm{SO}_{2}$ and $\mathrm{NO}_{2}$ concentrations in the air the secondary cortex thickness is slightly reduced and makes $87.9 \%$ of the reference rate. This is due to the depletion of the conducting phloem. The bast thickness in F. excelsior plants in Monitoring point 1 holds steady compared to the control index and in Monitoring point 2 it goes down by $10.1 \%$ because of the significant increase in the width of hard bast (Table 2). In our opinion, it can strengthen the stem supporting function under exposure of sulphur (IV) and nitrogen (IV) oxides and it is a compensatory response to shortening of wood radius (Table 3).

\section{The impact of industrial pollution on the structure of the stem wood and pith of woody plant undergrowth}

It is known that changes in the size and value of histological elements of secondary xylem may affect the upward transportation of substances in a stem, which can further affect drought resistance of woody and brushwood plants in the steppe zone. The chronic influence of industrial emissions can reduce this property. Arsenyeva \& Chavchavadze (2001) focused on the quantitative changes in the structure of water-conducting system of coniferous plants P. sylvestris and Picea obovata Ledeb, which stem from air pollution caused by sulphur dioxide. This includes reducing the annual wood increments and increasing latewood share due to reduction of the cambium activity and the formation of fewer elements of early wood.

Khvatova (2000) studied the impact of steel-manufacturing industry emissions on the anatomical structure of annual shoots of Populus L. plants and found such changes in the conducting system of the secondary xylem as shorting the vessel segments and their diameter, increasing the number of vessels per square millimetre. Shcherbinina (2004) investigated the teratogenesis processes in plants of Betula pubescens Ehrh. and T. cordata, which grow along the motorway. The scholar was observing the emergence of features inherent in the early stage of abnormal wood formation such as medullary rays expansion and abnormal growth of parenchyma cells in the total xylem cell volume marked by the decrease of vessel share in it [12]. Young plants of P. sylvestris, growing in an emission zone of aluminium and chemical plants are marked by formation of loose-textured wood and reduction of its radial growth increment [28]. 
The analysis of the data obtained in this study shows that the wood thickness decreases compared to the reference values in the undergrowth stems of A. platanoides by 20.8 and those of F. excelsior by $19.9 \%$ in case of high concentrations of emissions of Dnipropres. In Monitoring point 2 the change of this index is statistically insignificant in Norway maple undergrowth whereas in F. excelsior this parameter is significantly reduced compared to control plants (by $35.0 \%$ ). As stem xylem performs water and mineral conducting as well as supporting functions, significant reduction in the wood radius under man-made plant growth conditions may affect both the water supply of tissues and organs of the understory and its resistance to strong winds, which are also characteristic of the steppe zone of Ukraine. Consequently, the secondary xylem in the undergrowth stems is highly sensitive to industrial pollutants, as evidenced by changes in its quantitative indicators.

Among the components of the central cylinder of the studied woody species, the pith has the greatest volume in the stem diameter both under the normal and stress habitat conditions (Table 3 ). We also found that in stems of $A$. platanoides the pith is of rounded-edge and elliptical shape, so we could measure the large and small radii. In the undergrowth of the both species the reduction of the pith thickness is only statistically significant in Monitoring point 1, where both the minor and major stem diameters in A. platanoides reduce by $15.1 \%$ and $28.1 \%$ respectively compared to the control values, as well as the core diameter reduces by $23.9 \%$ in $F$. excelsior representatives.

The peripheral part of the pith in the stems of the research objects is perimedullary zone, which consists of small-sized well-lignified cells that perform a storage function. In the former species, it is mostly above the beams of vessels, and its thickness holds steady compared to the reference values when the plants are exposed to industrial emissions of $\mathrm{SO}_{2}$ and $\mathrm{NO}_{2}$ (Table 3). In the latter species the perimedullary zone thickness exceeds the reference value by $36.0 \%$ in the area of average pollution, which may be related to the increased storage of nutrients, though the perimedullary zone width remains similar to the control index in Monitoring point 1.

\section{The impact of industrial pollution on the stem diameter of woody plant undergrowth}

The changes in the thickness of the histological elements of the axial cylinder of the woody species undergrowth stems influence both the stele size and the stem diameter. The previous research showed the negative impact of aerogenic pollutants on the stem diameter growth in some woody species seedlings. Whitmore \& Freer-Smith (1982) found a decrease of this indicator for T. cordata, Betula pendula Roth., Populus nigra L. and B. pubescens under the influence of sulphur and nitrogen dioxides. The research of stem diameter in 1-3-year self-seedlings of $A$. negundo, exposed to industrial emissions of $\mathrm{SO}_{2}$ and $\mathrm{NO}_{2}$ revealed that in the area of average pollution this index is almost unchanged, but in the heavily contaminated area it drop significantly compared to the reference value in the self-seedlings of all age stages [29].

In our study, the diameter of the stem central cylinder in A.platanoides and F. excelsior plants decreases only in the area of high pollution, and the minor and major diameters of the former species by $16.7 \%$ and $24.3 \%$ accordingly, in the latter species the stem central cylinder diameter goes down by $18.5 \%$. In the area of average concentrations of toxic gases in the air, this characteristic does not change. We obtained similar results in the study of the stem diameter; it decreases only in the area of high pollution with $\mathrm{SO}_{2}$ and $\mathrm{NO}_{2}$. This anatomical parameter falls because of depletion of almost all stem histological elements in the undergrowth of $A$. platanoides and through thickness reduction of such stem parameters as the wood, the pith and the primary cortex (mainly of cork) in the plants of $F$. excelsior. 


\section{Conclusion}

The research findings confirm that man-made pollution of sulphur and nitrogen dioxides cause quantitative changes in the thickness of the histological elements of the undergrowth stems of the both studied species. In the aggregate of the annual shoots anatomical parameters, the undergrowth of $F$. excelsior prove to be more resistant to the chronic exposure to toxic gases, and the understory of $A$. platanoides appeared vulnerable.

The histological characteristics of the stem, which have appeared to be the most sensitive to sulphur (IV) and nitrogen (IV) oxides are the following: the wood radius, the primary cortex thickness, and the stem diameter. We suggest using these indices as informative test parameters for phytoindication of the state of the virginal plant cluster in the green belt of the anthropogenic areas in conditions of chronic emissions of $\mathrm{SO}_{2}$ and $\mathrm{NO}_{2}$ (test object $A$. platanoides).

\section{References}

[1] R.O. Striletz et al., Ecological Passport of Dnipropetrovsk Region (2013), Available at http://www.menr.gov.ua

[2] I.O. Zaitseva, L.G. Dolgova, Phisiological-biochemical Basis of Woody Plants Introduction in the Steppe Prydniprovya, Dniproperovsk, Dnipropetrovsk National University Press, Dnipropetrovsk, Ukraine, 2010.

[3] O.V. Brajon, V.G. Chikalenko, Plant Anatomy, Vyscha Shkola Publ., Kyiv, Ukraine, 1992.

[4] J. Albrerhtova, Plant Anatomy in Environmental Physiology, Prague, Czech Republic, 2004.

[5] T.V. Arsenyeva, E.S. Chavchavadze, Ecological and Anatomical Aspects of Pinaceae Wood Variability in the Industrial Areas of European North, Nauka Publ., Russia, 2001.

[6] W. Dmuchowski, E.U. Kurczynska, W. Wloch, Chemical Composition of Needles and Cambial Activity of Stems of Scots Pine Trees Affected by Air Pollutants in Polish Forests.

USDA Forest Service Gen.Tech.Rep. PSW-GTR-166. 1998 Available at http://www.fs.fed.us/psw/publications/documents/psw_gtr166/psw_gtr166_003_dmuchowski. pdf.

[7] V.V. Stasove et al., The Influence of the Complex of Technogenic and Recreational Burden on the Development of the Stem Tissues of Scotch Pine in Krasnoyarsk forest-steppe, News of RAS. Biological Series. 5 (2009) 618-626. (in Russian)

[8] M. Golikova, Influence of Industrial Pollution on Anatomic Structures of Shoots of Maples, Visnyk of Lviv University, Biological Series. 57 (2011) 242-248.

[9] Z.V. Griztay, L.V. Shupranova, Impact of Emissions of Pridneprovsk TPP in Dnipropetrovsk on the Anatomical Indices of Stem of Two-Year Whip of the Tilia Genus Representatives, Visn. Dnipropetr. Univ. Ser. Biol. Ekol. 23(2) (2015) 230-235.

[10] T. Iusypiva, G. Miasoid. The Impact of $\mathrm{SO}_{2}$ and $\mathrm{NO}_{2}$ Industrial Emissions on Anatomical Stem of Salix alba, International Letters of Natural Sciences. 51 (2016) 6-13.

[11] V.N. Khvatova, Changes in Microstructure of Annual Shoots of Populus under the Influence of Industrial Emissions, Voronezh State University Press. 2 (2000) 174-178. (in Russian)

[12] A.A. Shcherbinina, Display of Abnormal Growth of Woody Plants in the Affected Area of Main Highways, Thesis for a Candidate's Degree in Ecology, Moscow, Russia, 2004.

[13] V.P. Bessonova, The Influence of Heavy Metals on Photosynthesis of Plants, Dnipropetrovsk, Dnipropetrovsk State Agrarian University, Dnipropetrovsk, Ukraine, 2006.

[14] P.S. Pasternal, V.N. Voron, N.A. Khymenko, The Resistance of the Woody and Shrub Plants to Industrial Emissions under Conditions of Ukrainian Polesye, Forest Science and Afforastation Amelioration. 79 (1989) 67-71.

[15] Huang Ji-Shan et al., Damage of Simulated Acid Rain to Tree's Mesophyll Cells, Forest Research.15(2) (2002) 219-224.

[16] M.E. Whitmore, P.H. Freer-Smith, Growth Effects of $\mathrm{SO}_{2}$ and/or $\mathrm{NO}_{2}$ on Woody Plants and Grasser During Spring and Summer, Nature. 300 (1982) 55-57. 
[17] M.V. Zhuk, V.P. Krul, The Allocation of Pproductive Forces and the Economy of the Regions in Ukraine, Instruction Manual, Ruta Publ., Chernivtsi, Ukraine, 2002.

[18] Agroclimatic guide for Dnipropetrovsk region, Leningrad, Hydrometheoizdat Publ., USSR, 1958.

[19] The City of Dnipropetrovsk, Amending the general plan of the city development, Kyiv, Ukraine, 2015.

[20] N.A. Yemets, Ya.Ya. Serdyuk, Assessment of the Dnepropetrovsk City Territory Regarding the Level of Air Basin Contamination, Ecology and Natural Resource Management. 6 (2003) 200-207.

[21] M.M. Peremetchik, S.Z. Polischuk, Building the Map Charts of Atmospheric Contamination to Assist the System of Ecological Monitoring in the City of Dnipropetrovsk, 2011, Available at http://www.eco.com.ua

[22] H.V. Pasichnyi, V.M. Serdyuk, The Dynamics of Heavy Metals in Ground Source due to Technogenic Contamination of the Environment (Evidence from the City of Dnipropetrovsk), Ecology and Natural Resource Management. 4 (2002) 111-117.

[23] Information on: https://maps.visicom.ua

[24] D. Kim, Coder Advanced Tree Biology: Tree Anatomy I, University of Georgia, Available at http://www.isaarbor.com/events/conference/proceedings/2014/2014_DrCoderTREEANATOMY.pdf.

[25] T. Jusypiva, O. Podolkina, Influence of Industrial $\mathrm{SO}_{2}$ and $\mathrm{NO}_{2}$ Emissions on Histological Parameters of Robinia pseudoacacia L. Self-Sown Plants and Underground, Visnyk of Lviv University, Biological Series. 53 (2010) 106-113.

[26] T. Jusypiva, Woody Undergrowth: Stem Anatomy and Industrial $\mathrm{SO}_{2}$ and $\mathrm{NO}_{2} \mathrm{Pollution}$ NATO Advanced Research Workshop (ARW): 'Environmental and food security and safety in southeast Europe and Ukraine, Dnipropetrovsk, Ukraine, 16-19 May, 2011, pp. 57-58.

[27] C.B. Beck, An Introduction to Plant Structure and Development. Plant Anatomy for the Twenty-First Century, Cambridge University Press, 2010.

[28] I.N. Pavlov, Woody plants under Conditions of Technogenic Pollution, Ulan-Ude, Russia, 2005.

[29] T.I. Usypiva, Changes of Anatomic Indices of Stem of Acer negundo L. Self-sown Plant under the Influence of Toxic Gases of $\mathrm{SO}_{2}$ and $\mathrm{NO}_{2}$, Faltsfein Readings, in Collection of Research Papers, PP Vyshemirsky Publ., Kherson, Ukraine, 2007, pp. 384-386. 